\title{
The relationship between distance-to-default and CDS spreads as measures of default risk for European banks
}

\author{
Kim Ristolainen ${ }^{1}$ \\ University of Turku, Finland \\ kim.ristolainen@utu.fi
}

Received: 24 January 2016 / Revised: 17 March 2016 / Accepted: 3 April 2016 / Published online: 27 April 2016

\begin{abstract}
CDS spreads are often seen as the 'leading' market based, default risk measure. There is no popular alternative to CDS spreads except perhaps for the distance-to-default (D2D) measure based on Merton (1974), which comes very close to it. In this paper, we investigate the correlation and short-term dynamics between these two measures for large European banks with a data panel spanning from $1 / 2006$ to $12 / 2013$. The analysis makes use of conventional Granger causality test statistics for individual banks and for the whole panel data. As regards the results, we found that the lead-lag relationship between these highly related variables varies over time, over different banks, and over economic regimes. The lead of D2D is significantly stronger for banks that are smaller relative to the other banks in the sample, banks in problem countries (PIIGS), after global financial crises, during market turmoil, and for banks with poor credit quality indicated by a high CDS spread. These results and the fact that D2D can be calculated for every bank quoted on the stock exchange suggests that D2D is a promising alternative to the CDS spread in default risk assessment of banks.
\end{abstract}

JEL Classification: G01; G21; G32.

Keywords: financial stability, European banks, distance-to-default, credit default swap, lead-lag relationship.

\section{INTRODUCTION}

The recent financial turmoil that started from the subprime crises and spread to European banks and ultimately escalated into a sovereign debt crises, has increased interest in the stability of the banking system. The collapse of Bear Stearns, Merrill Lynch, AIG, and many other financial institutions has raised the question of the market's failure to anticipate the default risk of banks. There is clearly an increasing need for financial stability tools that policy makers could use to detect and possibly prevent such events in the future. The early warning system (EWS) literature has developed models that aim to predict financial crises beforehand, in a given time window, using information from so called crises indicators. These crises indicators are usually motivated

1 Corresponding author. Telephone: +358443267511, Postal Adress: Department of Economics, University of Turku, FI-20014, University of Turku. 
by economic theory and consist of macroeconomic and financial variables such as real GDP growth, inflation, stock prices, credit growth etc. Kaminsky, Lizondo and Reinhart (1998) and Berg and Pattillo (1999) have written the seminal papers in the field. The former used a univariate signals approach to predict currency crises and the latter used a multivariate probit regression for the same purpose. The literature has since adopted more advanced models such as classification and regression trees and different kinds of artificial neural networks, to name just a few. This literature is heavily concentrated on predicting different kinds of financial crises, but very little emphasis is placed on the default risk of individual banks.

In addition to bond yield spreads, a common indicator of a default risk for banks used among investors, analysts etc. is the price or spread of a credit default swap (CDS). The CDS is a contract used to transfer the default risk of an entity from the buyer to the seller of the contract. The buyer of a CDS makes payments to the seller until the maturity of the contract in an exchange where the seller compensates the losses of the buyer in the case of a default event. The price of the CDS is the annual payment to the seller, in basis points, of the underlying reference asset. The more riskier markets see the bank, the larger the CDS spread has to be. This market based risk measure is appealing, as it has been shown to lead bond spreads in the price discovery process. However, there is a major practical drawback in the application of CDS spreads in financial stability monitoring. CDS contracts are available for around 100 banks; usually these banks tend to be among the largest financial institutions. The aim of this paper is to study the performance of another default risk measure based on Merton (1974) called distance-to-default (D2D), which can be calculated ${ }^{2}$, in practice, for every bank that is quoted on the stock exchange. D2D has been used as a control for credit risk instead of credit ratings (Ahmed, Anderson and Zarutskie, 2015; Acharya, Lochstoer and Ramadorai, 2013) and it has been proven to have some success in default prediction (Bharath and Shumway, 2008). Harada, Ito and Takahashi (2010) and Milne (2014) concluded that D2D does not predict the failure of banks. However, the latter study found some predictive power in the D2D values of mid-2008 over the bank failures of the end of that year. Nevertheless, this measure has not been studied extensively in the literature, which is why we want to compare its performance in the default risk assessment of banks' with a 'leading' market based measure such as the CDS spread.

A simple correlation analysis with a five year rolling window revealed that CDS spreads and D2Ds are highly related, but in some cases the measures indicate a change in the default risk into the opposite direction. We studied the short-term dynamics of these measures with a conventional Granger causality analysis in a VAR framework at the panel and individual bank level, because the lead of D2D over CDS spread would indicate that the former measure implies the change in default risk earlier than the latter - in other words performs better. The panel VAR model was estimated with fixed bank effects to control for bank specific unobserved heterogeneity, such as the bank's credit rating. We used a panel of monthly data spanning between 1/2006-12/2013 for 37 banks with a total of 3023 observations. Our results show that the D2D Granger causes the CDS spread at the panel level in both differences, and levels with a lag of one month. The lead was also significant and unidirectional from the D2D to the CDS spread when a longer lag length of two months was chosen in the model specification with the Schwartz Bayesian information criterion. The lead of one month was shown to strengthen through the European debt crises when the model is estimated with a three year rolling window. The direction of the causality varies greatly across banks as we found as many banks with the D2D leading the CDS spread as banks with causality in the other direction. In further analysis, with conditional dummy variable interaction terms added to the panel VAR model, we found that the strength of the D2D over the CDS spread depends on general market conditions and bank specific characteristics. The lead is significantly stronger during market turmoil and after the beginning of the global financial crises.

The credit rating agency Moodys' analytical service KMV has commercialized this measure with their own estimation method using historical default data to extract default probabilities from D2D. 
In addition, if the bank is located in a 'problem' country or has low credit quality indicated by a high CDS spread, then the lead of distance-to-default over CDS spread is stronger. Also banks with smaller market capitalization than the sample's median have a stronger lead of D2D over CDS spread. This affect is the other way around when the bank is located in the PIIGS countries as the coefficient of our double interaction dummy for these characteristics is negative, and highly significant. Moreover, a turmoil month combined with the fact that the bank is located in PIIGS countries or has a high CDS spread has a similar effect on the lead of the D2D.

As CDS markets have been shown to be information efficient in many studies (Zhang and Zhang, 2013; Blanco, Brennan and Marsh, 2005), the superior performance of the distance-todefault over the CDS spread in indicating changes in default risk of banks has to be due to the theoretical background of this measure. In addition to our promising results for the distance-todefault, the fact that the D2D's assumptions have been shown to be quite robust to deviations (Jessen and Lando, 2015) makes this default risk measure a very good alternative to the most commonly used market based early warning indicator. As the D2D is also available for a much broader range of banks and not only the largest ones, the D2D is also a better measure from a practical point of view. Other variables such as equity price (Acharya and Johnson, 2007) and the average overnight borrowing spread (AOR) (Tolo, Jokivuolle and Viren, 2015) have also been shown to lead the CDS spread ${ }^{3}$; however, this is so far the only study that we know of where a variable has been shown to have predictive power over the future values of the CDS spread by as much as one or two months before the actual realizations of the CDS price.

This paper is organized as follows: in sections 2 and 3 we discuss the calculation and specifics of distance-to-default and CDS spread as a default risk measure. In section 4, the dataset for empirical analysis is introduced. Section 5 explains the empirical methodology used in the paper to study the relationship between the two measures. The empirical results and their economic implications are also discussed in the same section. Finally section 6 provides a conclusion.

\section{DISTANCE-TO-DEFAULT}

Distance-to-default is a default risk measure derived from Merton (1974) theoretical credit risk model, which treats a firm's equity $E$ as a call option on the firm's assets $A$. This means that equity holders obtain the rest of the value of assets after bondholders have received their debt $D$ at the maturity $T$ of the debt. This way the equity value can be presented as $E=\max (A-D, 0)$. Distance-to-default is simply the distance between the expected value of assets $A$ and the default point, which is the value of debt $D$. In other words, the firm is expected to default if its assets fall below the level of the debt.

$$
D 2 D=\frac{\log \left(\frac{A}{D}\right)+\left(\mu-\frac{1}{2} \sigma_{A}^{2}\right)(T-t)}{\sigma_{A} \sqrt{T-t}}
$$

From the D2D formula in the equation 1 one can see that a lower leverage ratio gives a higher D2D value, when other parameters are kept unchanged. The same effect occurs with a higher expected return of assets. The higher volatility of assets increases the value of the D2D when the numerator of the equation 1 is positive. This makes sense as we would expect the likelihood of a default for a more leveraged firm to be higher. Moreover, when the firm's expected growth of assets has risen, then the likelihood that it can pay its debts must be higher. Intuitively the

A relevant issue that needed to be checked was the possibility that the stock returns explain most of the variation in the values of the D2D and thus its lead over the CDS spread. This seems not to be the case as the portion of the explained variance in the D2D for the liabilities in the balance sheet is almost the same as for the stock returns. 
more volatile the returns are, the more likely it is that the assets will fall below the debt level. The critical assumptions of the model are that:

- $\quad$ debt is homogeneous with maturity $T$

- $\quad$ there are no market frictions

- $\quad$ firm's capital structure is $A=D+E$

- $\quad$ firm's asset value $A$ follows a geometric Brownian motion $d A_{t}=\mu A_{t} d t+\sigma_{A} d S_{t}$, where $\mu$ is the drift of the asset value and $S$ is a standard Brownian motion

- $\quad$ Economic agents are also assumed to be risk neutral, which makes the estimation much simpler as $\mu$ can be replaced with the risk-free rate $r$ in formula 1 .

The problem within the formula is that we cannot observe the value of the assets $A$ or their volatility $\sigma_{A}$. However, due to the option interpretation of the firm's equity, we can present the value of the firm's equity at time $t$ with the Black and Scholes (1973) option pricing formula:

$$
\begin{gathered}
E_{t}=A_{t} \phi\left(d_{1}\right)-e^{-r(T-t)} D \phi\left(d_{2}\right) \\
\sigma_{E}=\frac{A}{E} \frac{\partial E}{\partial A} \sigma_{A}
\end{gathered}
$$

here $d_{1}=\frac{\log \left(\frac{A}{D}\right)+\left(r-\frac{1}{2} \sigma_{A}^{2}\right)(T-t)}{\sigma_{A} \sqrt{T-t}}$ and $d_{2}=d_{1}-\sigma_{A} \sqrt{T-t}$. The unobservable asset value and its volatility can be solved from the system of nonlinear equations consisting of the equation 2 and the relationship between asset and equity volatility in the equation 3 . Before we can obtain the asset value and volatility, we must collect the debt value from the firm's balance sheet, the risk-free rate, and the equity value and volatility from the stock price data. One of the most often used application of D2D is Moody's KMV method where the debt maturity $T$ is set as 1 year and the debt variable is constructed as the sum of short term debt and one half of the long term debt. This is justified by historical data from KMV's default database, which indicates that typically firms default when the asset are somewhere between the total debt and the short term debt (Crosbie and Bohn, 2003). This is also the method used in this paper.

Figure 1

Average negative of distance-to-default for 37 large European banks from 2008 to 2014

Average negative of $\mathrm{D} 2 \mathrm{D}$ across banks

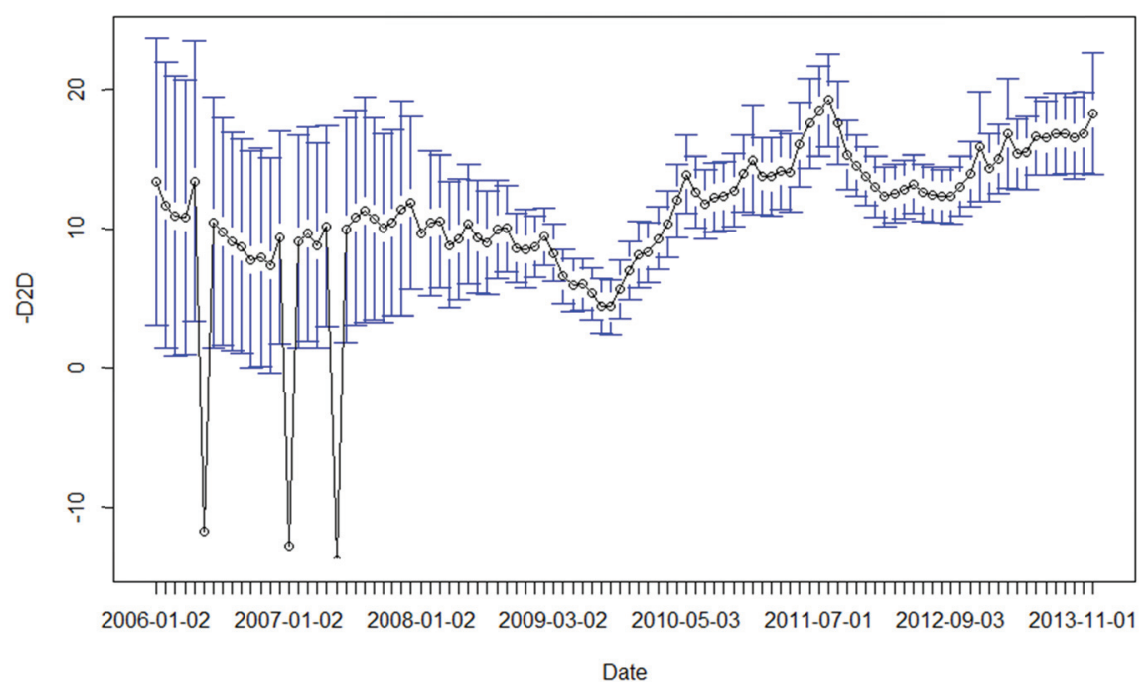


The calculation of the distance-to-default for banks has few problems, when compared to nonfinancial firms. Firstly financial regulators usually take action before the actual default occurs, because of the considerable effect bank defaults have on the economy, due to the collapse of the credit supply. Sy and Chan-Lau (2006) introduced a modified measure called distance-to-capital, which corrects the leverage ratio of $\mathrm{D} 2 \mathrm{D}$ with the statutory minimum capital adequacy ratio. The other more severe problem with the banks D2D derivation is the divergence of a financial firm's balance sheet from that of a non-financial firm. Banks have different kinds of deposits, derivative liabilities, and trading liabilities in their balance sheets. It is hard to define the maturity of these liabilities. In this paper, we use a capital adequacy ratio of $12 \%$ to correct the leverage ratio and we define deposits as short term debt and exclude derivative and trading liabilities ${ }^{4}$.

\section{CREDIT DEFAULT SWAPS}

Credit default swaps (CDS) are usually used as protection from credit risk. If an investment bank wants to hedge from the default risk of a corporation whose 5-year maturity bond is held by the bank, the bank can buy a 5-year maturity CDS contract from a third party. These CDS contracts are usually traded in over-the counter (OTC) markets. Then the bank pays annual fees to the CDS seller in exchange for the repayment of the rest of the debt, if a default occurs before the maturity of the bond. This annual fee is referred to as the CDS price or CDS spread, which is expressed in basis points. The payments to the seller are usually made more frequently e.g. quarterly. If the corporation does not default during these five years, then the seller keeps the annual fees as profit from the default risk he/she has borne on behalf of the bank. If a default occurs before the maturity of the CDS contract, then the seller keeps the fees he/she has collected from the buyer and compensates the credit loss to the bank. This compensation is usually done by physically delivering a reference asset or by a cash settlement. Because of the full protection the buyer of the CDS receives against the credit risk of the reference entity, there is a very close relationship between the CDS price and the bond spread ${ }^{5}$. This relationship has been investigated in numerous papers (Blanco et al., 2005), because of the possible arbitrage opportunity between the two financial instruments.

\section{Figure 2}

Average CDS spread for 37 large European banks from 2008 to 2014

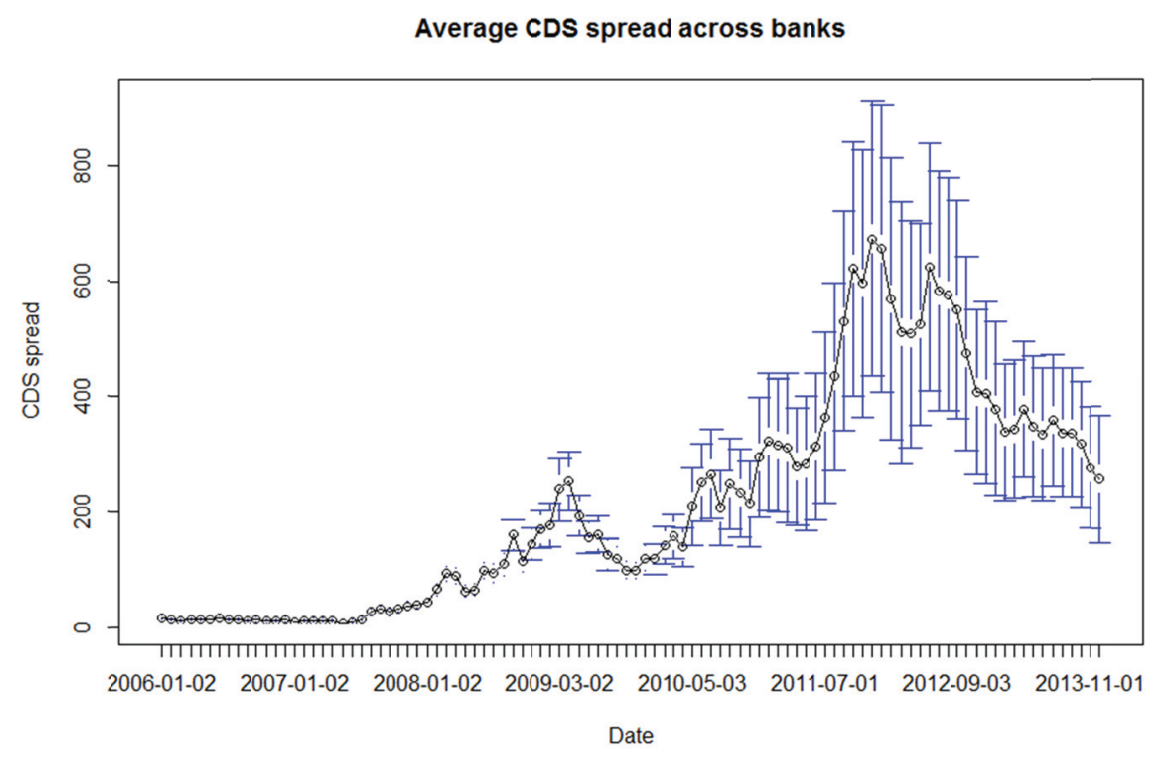

Keeping derivative and trading liabilities in the calculation either as short term or long term did not seem to affect the results significantly.

Bond spread or the credit spread is the difference between the bonds rate and the risk-free rate. 
In addition to hedging from credit risk, CDS spreads are also used as early warning indicators of the weak state of the bank. A rapid decline in the bank's creditworthiness raises the CDS spread, as the insurer of the reference entity or the seller of the CDS will demand a larger fee against the greater risk that he/she has to compensate for against the credit losses of the CDS buyer. It is possible to extract default probabilities from the CDS spread as it is seen as a function of the default probability and the recovery value. This recovery value is usually assumed to be a constant, but Duffie (1999) have stressed that this assumption is not correct in all circumstances. There are few aspects why the CDS spread might not entirely reflect the bank's credit risk. Firstly, the very popular post-2008 research subject of bank's that are too-big-to-fail. Vlz and Wedow (2011) found that the CDS spreads of large banks are distorted, because they are thought as too-big-to-fail. This might affect the CDS spread in a downgrading way. Secondly the liquidity of a CDS contract may have an effect on the price. The results in the papers investigating the direction of this effect are mixed, but a higher liquidity is usually expected to lower the CDS price. Lastly, the restructuring of the debt is also seen as a default event for CDS contracts in Europe. This means that a cheapest-to-deliver option is also included in the CDS spread, because a physical settlement can be done with some reference entities with discounts.

\section{DATA DESCRIPTION}

The monthly dataset used in this paper is from January 2006 to December 2013 and includes 37 large European banks. Originally, we had balance sheet data for over 90 banks, but the ones that were not listed had to be omitted, because stock prices are needed to calculate the distanceto-default. The list of banks were also reduced, because the CDS transaction data was available for an even smaller subset. We used monthly credit default swap spreads that were averaged over daily transaction prices from Datastream. The CDSs used in the analysis are senior five year contracts that is by far the most liquid traded maturity. The data started for some banks as early as 2003, but the majority could only be collected as late as 2008 or even later. Because of this, the number of monthly observations varies across the banks from 42 to 96 , so that the total number of observations was 3023 .

Table 1

Descriptive Statistics

\begin{tabular}{lccccc}
\hline \hline & $\mathrm{N}$ & Mean & St.Dev. & Min & Max \\
\hline CDS spread in basis points & 3,023 & 235 & 350 & 1 & 2,646 \\
D2D & 3,023 & -12 & 12 & -67 & 68 \\
Market capitalization in million \$ & 3,023 & 166,97 & 991,105 & 39 & $11,800,000$ \\
Volatility of returns & 3,023 & 0.204 & 0.131 & 0.049 & 1.381 \\
12-month euribor in \% & 3,023 & 2.301 & 1.533 & 0.478 & 5.495 \\
S-T liabilities and deposits in million \$ & 3,023 & 305,094 & 305,059 & 17,514 & $1,261,480$ \\
L-T liabilities in million \$ & 3,023 & 90,272 & 92,046 & 708 & 717,854 \\
Total liabilities in million \$ & 3,023 & 579,218 & 609,394 & 22,456 & $2,423,755$ \\
\hline \hline
\end{tabular}


The variables that were needed to calculate the monthly distance-to-default were mainly assembled from Macrobond. The market capitalization averaged from daily observations was used as the value of the equity and the annualized volatility calculated with a 12 month rolling window from daily stock returns as the volatility of equity. Annual balance sheet data ${ }^{6}$ was collected from Bankscope and used with the same value for all months of that year. Semi-annual or quarterly data would have been available for a large portion of the banks, but only for the last two or three years. Annual balance sheet data might be an issue, because the other variables have new information on a daily frequency, which is then aggregated to a monthly frequency. This problem would in all likelihood appear as large movements in the distance-to-default value at every January when the new information replaces the assumed old information of the later months of that year. We did not observe this kind of general behaviour in the values, so we proceeded to further analysis with the same data. The debt variable of a bank is the sum of the short term $(<1$ year) debt and one half of the long term debt $(>1$ year).

The conditional dummy variables used in the panel VAR analysis were divided into the general market condition dummies and bank specific characteristic dummies. The former group consists of dummies for different crises periods and of a market turmoil variable. The turmoil dummy is constructed from information from the ITRAXX, which is an index of CDS spreads for large European financial firms. The turmoil dummy is equal to one for the months when the index is above its sample median. The bank specific characteristic variables are derived in the same manner. The high CDS spread is equal to one when the bank has a higher CDS spread than the median of that months CDS spread among the banks. The high liabilities to equity ratio dummy is equal to one if bank has a higher value than the sample median. The bank size variable is constructed in the same way by using banks' market capitalizations. The bank default information used to assemble the bank default variable was mainly collected from Failed Bank Tracker ${ }^{7}$, which lists bank bailouts, nationalizations, mergers, bankruptcies, defaults etc.

\section{EMPIRICAL ANALYSIS}

As both CDS spread and D2D are measures of default risk, then despite the presence of some short-term deviations they should be highly related to each other. Figure 3 displays a heatmap of simple correlation coefficients for each bank individually calculated with a five year rolling window. As the decline of D2D and the rise of the CDS spread should indicate an elevated default risk of a bank, then the correlation between the two variables should be negative. It seems that for about half of the banks this is the case most of the time, but interestingly, for many banks there seems to exist a high positive correlation between the two measures for certain time periods. For the banks that have this unexpected result, the correlation seems to be positive for only the beginning of the sample and after that the correlation changes to slightly negative or becomes close to zero. This means that for some banks the measures indicate a change in the default risk in opposite directions.

These correlation coefficients could be explained by the D2D theoretical background, which is designed to indicate weaknesses in the bank's balance sheet. The rise of the default risk indicated by a declined D2D value for a bank can either be due to a risen leverage, smaller expected asset returns or higher asset volatility ${ }^{8}$. All of these things should also be reflected in the CDS prices at some level as well. As the negative relation between the indicated default risk by the

\footnotetext{
Deposits, short term liabilities and long term liabilities excluding derivative and trading liabilities.

See http://openeconomics.net/failed-bank-tracker/.

This is the case when the numerator of D2D formula is positive. In another words, the bank's assets are expected to cover their debt. If the numerator is already negative then a high asset volatility raises the D2D value, because the likelihood that the value of the assets rises above the debt level is now higher.
} 
two measures is strong in the beginning of the sample for some banks, the banks balance sheet information could be more important during times of crises. This was seen during the start of the global financial crises as it became clear that the subprime mortgages banks held in their balance sheet were significantly more risky that was generally thought. Throughout the market turmoil it became increasingly important to know the exact content of a bank's balance sheet and especially exactly how much of the toxic mortgages each bank owned. In addition, the markets did not see the banks' high leverage ratios as a major problem before the crises. From the individual bank graphs of the two measures in Figure A1 it can be concluded that for most of the banks it has been exactly the case that the D2D 'warned' about a risen default risk before the actual eruption of the financial crisis, when the CDS spread indicated the opposite development.

\section{Figure 3}

Correlation of D2D and CDS spread calculated with a 5 year rolling window

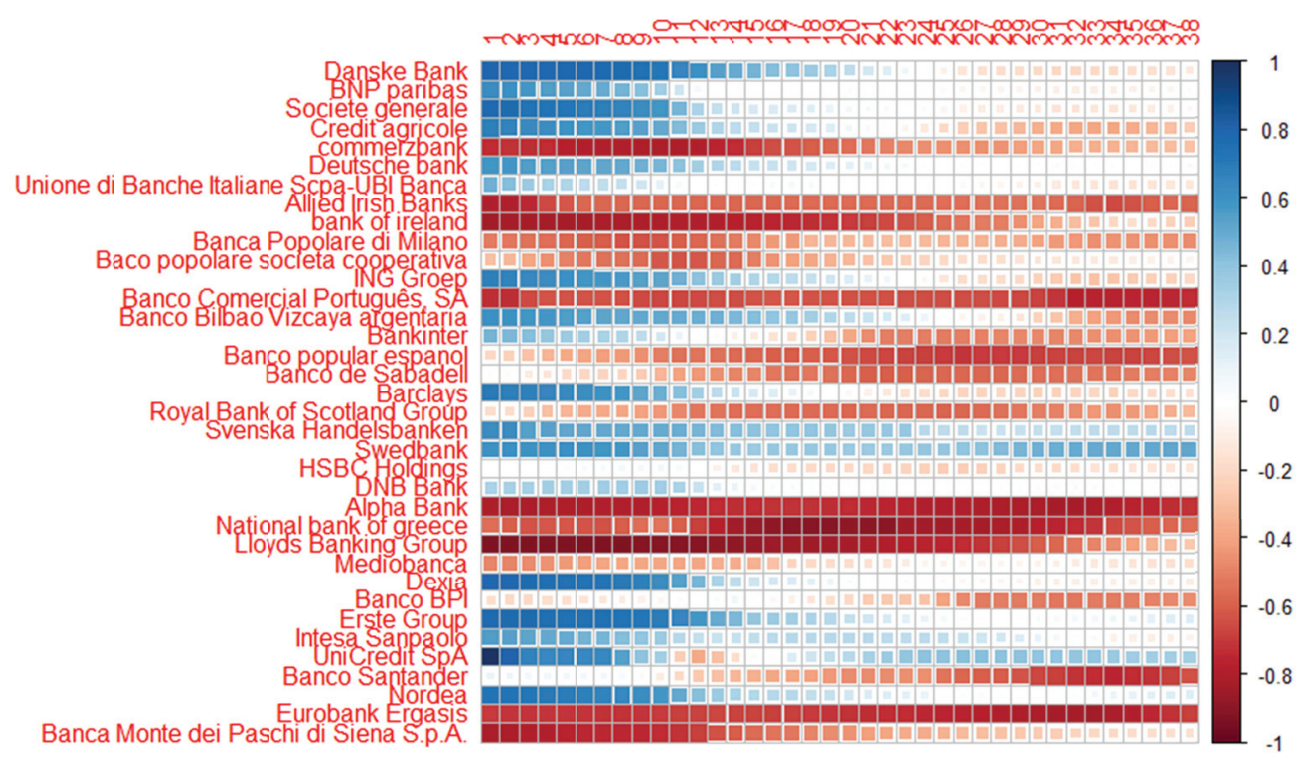

One explanation for the different indications of the measures might also be that sometimes D2D signals default risk changes too eagerly, for example, when banks are merged together and the balance sheet structure rapidly changes. However, this can not explain the significant amount of positive correlation between the measures in the sample. Possibly the markets do not see the balance sheet structure of certain banks as weak as the D2D does. These claims receive some support from the fact that eight of the nine banks that have defaulted in our sample since the financial crises have the expected very high negative correlation between the two measures, which indicates that both the D2D and the CDS spread have either indicated a risen default risk or not - in another words, the measures have agreed on the state of these banks at some level. Nevertheless, the bank's CDS spread and the D2D seem to be highly related.

In order to study a possible long-term relationship between the two measures, we tested for cointegration of the series at the panel level. An individual constant without a trend was assumed for the series in the test specification. A linear trend in a default risk measure would be quite counter intuitive, although this can be detected in some of the individual bank graphs as our sample starts from the beginning of the market turmoil of the subprime crises and ranges through the European sovereign debt crises when the default risks of European banks were generally rising (Figure 2). All of our panel unitroot tests reject the null hypothesis of a unitroot in the D2D series at a 1\% significance level, but the tests do not reject the null hypothesis for the CDS spread series. From a theoretical point of view, it would be hard to see why either of the measures would be nonstationary in general. A stochastic trend in the series would indicate that the credit risk for each bank would just rise or decline to infinity in the long-run, and all the banks would 
either go bankrupt or have a zero probability for default. Here we exercised some judgement, and conclude that CDS spreads are stationary at panel level given the theoretical and intuitive reasons mentioned earlier. These test results prevented us from using cointegration analysis in the panel setting.

However, we are more interested in the performance of the CDS spread and the D2D in the default risk assessment than their long-term relationship, which is why we will analyse the shortterm dynamics between the two measures with conventional Granger causality analysis in the vector autoregression (VAR) framework. In this way, we can possibly state that the other measure performs better in the sense that it leads the other measure. If this kind of relationship is detected, then we can conclude that the other measure indicated the change in default risk earlier than the other. The formal definition of the model used is:

$$
y_{t}^{i}=\alpha_{i}+\sum_{p=1}^{k} A_{p} y_{t-p}^{i}+\varepsilon_{t}^{i}
$$

where vector $\alpha_{i}$ represents the fixed bank effects, matrix $A_{p}$ holds the coefficients of the panel regression, $\varepsilon_{t}^{i}$ is the error term and finally vector $y_{t}^{i}$ contains the CDS spread and distance-todefault for bank $i$ at month $t$. With the fixed bank effects we can control for the unobserved heterogeneity of each bank. The model has been estimated with ordinary least squares (OLS) as it has been shown to give consistent estimators for dynamic panel models with macroeconomic data where $\mathrm{T}$ is large and $\mathrm{N}$ is relatively small (Juessen and Linnemann, 2010). We used heteroskedasticity and serial correlation consistent standard errors by Arellano (1987) in the inference.

Distance-to-default is the so called "challenger" in our analysis as the CDS spread is a more commonly accepted and widely used measure for a bank's default risk. Both of these measures are market based, but the theoretical background might give D2D an advantage over the CDS spread in assessing default risk. Given this motivation we tested the hypothesis 1 in our VAR-framework.

\section{Hypothesis 1.}

\section{D2D leads the CDS spread for European banks in the form of Granger causality}

Table 2 shows the results for the panel VAR model with fixed bank effects for two different lag lengths. We report the results for a short-term (S-T) lead-lag relation of one month, and also for a possible long-term (L-T) relation were the lag length was chosen to be two months by the Schwartz Bayesian information criterion (SBIC) from a maximum of 10 months. For robustness of the results we also report the same analysis for the differenced variables in Table A5, where SBIC chose a lag length of one month. Almost all coefficients are statistically significant and have the expected sign. Because a rising default risk of a bank should decrease the D2D and raise its CDS spread, the lagged D2D should have a negative coefficient in the CDS equation of the VAR model and vice versa. Only the variables that are lagged by two months in the CDS equation have the opposite signs against intuition. Neither of the variables seem to have predictive information on the value of the D2D two months ahead, as those coefficients are not statistically significant in the L-T CDS equation. Both models fit well as the coefficient of determination is the same for the S-T and L-T models $-95.3 \%$ for the D2D and 96.9\% for the CDS spread equation. The fact that the CDS spread is a price given in basis points and the distance-to-default is a value of how many standard deviations away a possible default is, makes a nonlinear relation between the two measures a justifiable alternative that needed to be tested. 
Table 2

Granger causality analysis of CDS and D2D with fixed effects VAR-model

\begin{tabular}{|c|c|c|c|c|}
\hline & \multicolumn{4}{|c|}{ Dependent variable } \\
\hline & \multicolumn{2}{|c|}{ Short-term } & \multicolumn{2}{|c|}{ Long-term } \\
\hline & $D 2 D_{t}$ & $C D S_{t}$ & $D 2 D_{t}$ & $C D S_{t}$ \\
\hline \multirow[t]{2}{*}{$C D S_{t-1}$} & $-0.001^{* *}$ & $0.945^{* * *}$ & -0.0008 & $1.033^{* * *}$ \\
\hline & $(0.0006)$ & $(0.016)$ & $(0.001)$ & $(0.045)$ \\
\hline \multirow{2}{*}{$D 2 D_{t-1}$} & $0.855^{* * *}$ & $-0.874^{* * *}$ & $0.753^{* * *}$ & $-1.194^{* * *}$ \\
\hline & $(0.032)$ & $(0.174)$ & $(0.083)$ & $(0.248)$ \\
\hline \multirow[t]{2}{*}{$C D S_{t-2}$} & & & -0.0004 & $-0.090^{* *}$ \\
\hline & & & $(0.001)$ & $(0.043)$ \\
\hline \multirow[t]{2}{*}{$D 2 D_{t-2}$} & & & 0.117 & $0.379^{*}$ \\
\hline & & & $(0.073)$ & $(0.221)$ \\
\hline H0: CDS does not Granger cause D2D & 0.023 & & 0.058 & \\
\hline H0: D2D does not Granger cause CDS & & 0.000 & & 0.000 \\
\hline Observations & 3,022 & 3,022 & 3,022 & 3,022 \\
\hline$R^{2}$ & 0.953 & 0.969 & 0.953 & 0.969 \\
\hline
\end{tabular}

Note: ${ }^{*} \mathrm{p}<0.1 ;{ }^{* *} \mathrm{p}<0.05 ;{ }^{* * *} \mathrm{p}<0.01$

Quadratic and cubic formulations were fitted, but the quadratic coefficients were not significant and none of the nonlinear model specifications improved the models fit ${ }^{9}$, which is why we followed the assumption of a linear relationship in further analysis. The short term results are consistent with the hypothesis 1, as the null hypothesis that the D2D does not Granger cause CDS spread is rejected at a $1 \%$ significance level. However, there seems to be a bidirectional Granger causality, as the null hypothesis of the CDS spread not Granger causing the D2D is also rejected with a 5\% significance level. The results are similar with the differenced variables except that we observed a unidirectional Granger causality from the D2D to the CDS spread. With the longer lag length the evidence is even stronger as we could not reject the null for the CDS not leading the $\mathrm{D} 2 \mathrm{D}$, but we reject the null of the D2D not leading the CDS spread at $1 \%$ significance level. It seems that at least the D2D has predictive power over the future values of a bank's CDS spread as early as one to two months before the realization of the current value of the CDS spread.

As we can accept hypothesis 1 with rather strong evidence, it would be interesting to see if the lead of the D2D over the CDS spread is stronger given certain general market conditions. Figure 4 displays the value and significance of the lagged D2D coefficient in the CDS spread equation when the model is estimated with levels and a three year rolling window. The lead of the D2D over the CDS spread seems to become more negative - in other words stronger - throughout the European debt crisis. The D2D theoretical background seems to have provided a major advantage over just using market information in the latter years of the ongoing crises. If there is major time heterogeneity in the D2D coefficient, the strength of the lead might also vary between different banks. Table A4 displays the results of the Granger causality analysis for different banks. Again we allowed the VAR-model to choose the lag length from a maximum of 10 months. In the case of 30 banks, a lag length of one month was chosen for the model, but interestingly for 6 banks a lag length of two months was chosen. For 20 banks an unidirectional causality is observed, when

These results are not presented in the paper, but can be given by the author when requested. 
a $5 \%$ significance level is used to reject the null hypothesis. In half of these cases the D2D leads the CDS spread, which again indicates that the strength of the lead might vary across different bank characteristics. For example, the domicile of seven of these ten banks where the D2D leads the CDS spread is in the so called PIIGS countries.

\section{Figure 4}

D2D coefficient and its significance in VAR-models CDS equation estimated with a three year rolling window from $C D S_{i, t}=\alpha_{0, i}+\alpha_{1} C D S_{i, t-1}+\beta_{1} D 2 D_{i, t-1}+\epsilon_{i, t^{*}}$ The number of observations span between 1005 and 1233

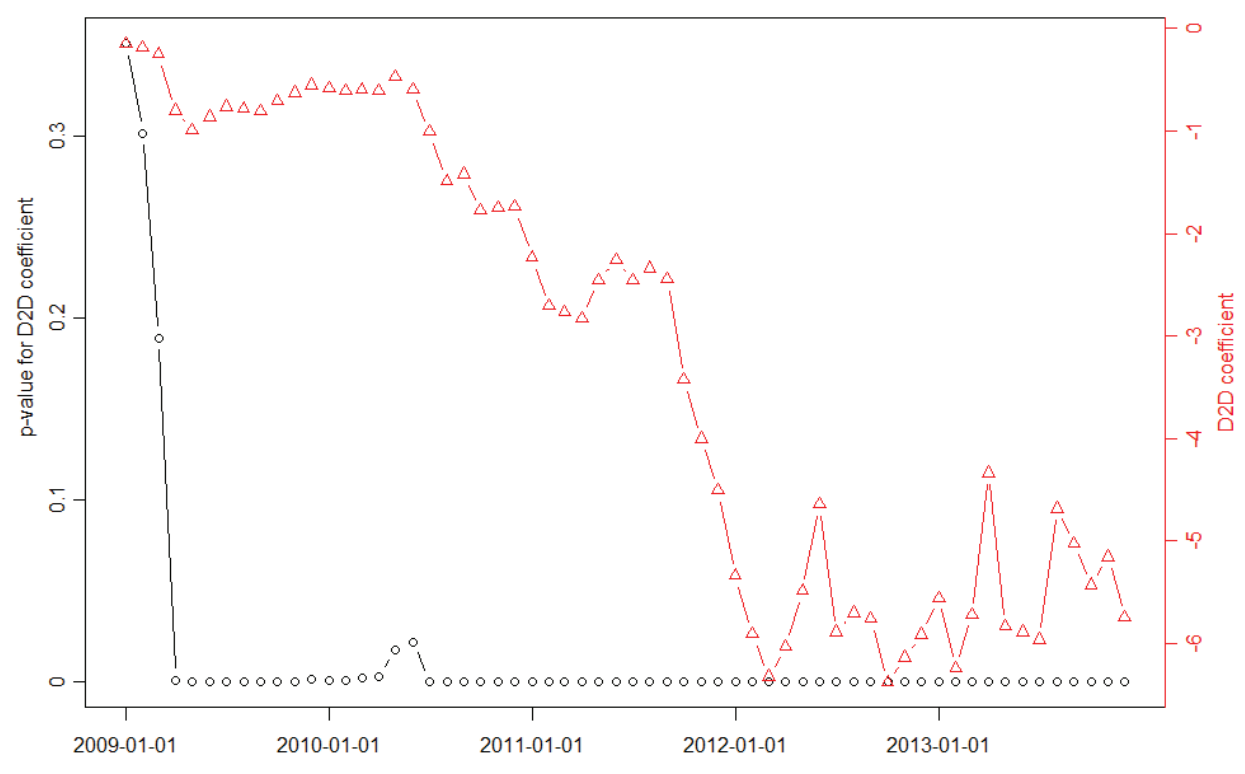

Table 3

Panel VAR results with conditional dummies

\begin{tabular}{|c|c|c|c|c|c|c|}
\hline Panel A & $C D S_{t}$ & $C D S_{t}$ & $C D S_{t}$ & $C D S_{t}$ & $C D S_{t} \mathrm{t}$ & $C D S_{t}$ \\
\hline$D 2 D_{t-1}$ & $\begin{array}{c}-0.023 \\
(0.274)\end{array}$ & $\begin{array}{c}-0.707^{* * *} \\
(0.160)\end{array}$ & $\begin{array}{c}-0.757^{* * *} \\
(0.163)\end{array}$ & $\begin{array}{c}-0.686^{* * *} \\
(0.164)\end{array}$ & $\begin{array}{c}-0.736^{* * *} \\
(0.167)\end{array}$ & $\begin{array}{c}-1.098^{* * *} \\
(0.421)\end{array}$ \\
\hline PRE LEHMAN LE-1 $_{t}(-2008)$ & $\begin{array}{l}0.623^{* *} \\
(0.260)\end{array}$ & - & - & - & - & - \\
\hline POST LEHMAN ${ }_{t-1}(2008-2010)$ & - & $\begin{array}{c}-0.712^{* * *} \\
(0.162)\end{array}$ & - & - & $\begin{array}{c}-1.045^{* * *} \\
(0.171)\end{array}$ & - \\
\hline EURO CRISIS ${ }_{t-1}(2010-)$ & - & - & $\begin{array}{c}-0.486^{* * *} \\
(0.149)\end{array}$ & - & - & $\begin{array}{l}0.481^{* * *} \\
(0.160)\end{array}$ \\
\hline TURMOIL $_{t-1}$ & - & - & - & $\begin{array}{c}-0.999^{* * *} \\
(0.161)\end{array}$ & $\begin{array}{c}-1.145^{* * *} \\
(0.167)\end{array}$ & $\begin{array}{c}-1.355^{* * *} \\
(0.179)\end{array}$ \\
\hline
\end{tabular}

In further analysis, we tested whether the strength of D2D lead depends on some specific market or bank condition by adding conditional dummy variable interaction terms with the D2D to the panel VAR model. The S-T model was used as the L-T model did not have a better fit, and because we wanted to use the simplest model possible. The formal definition of the model estimated is: $C D S_{i, t}=\alpha_{0, i}+\beta_{1} C D S_{i, t-1}+\beta_{2} D 2 D_{i, t-1}+\beta_{3} D 2 D_{i, t-1} D U M M Y_{i, t-1}$. Due to our data limitations we assembled a group with five conditional dummies for bank specific characteristics, and four conditional dummies describing general market conditions in order to test the hypothesis 
$2 i-2 v i$. The results in Table 3 show that the lead was significantly weaker before the global financial crises as the coefficient $\beta_{3}$ for the Pre-Lehman dummy interaction with the lagged D2D was negative and highly statistically significant. The lagged D2D coefficient $\beta_{2}$ in each model specification was negative and significant as expected, except for the first regression.

\section{Hypothesis 2.}

The lead of distance-to-default on credit default swap spreads is stronger
i) during crises times
ii) during market turmoil
iii) for more leveraged banks
iv) for banks in problem countries
v) for banks with poor credit quality
vi) for relatively small banks

This simply means that the decline of the distance-to-default raises the CDS prices in the next month. The regressions with the Post-Lehman, European debt crises and the turmoil dummy interaction terms show that the lead also becomes significantly more negative during financial crises - especially the first two years - and during the market turmoil, which is indicated by the high values of the European financial ITRAXX index. When the crises interaction dummy terms are included concurrently in the model with the turmoil interaction term, the Euro Crises coefficient stops being significant, but the Post Lehman interaction remains negative and significant together with the turmoil interaction coefficient. Given these results we can accept hypothesis 2 i)-ii) of a stronger lead of the D2D over the CDS spread during times of crises and market turmoil.

Table 4

Panel VAR results with conditional dummies

\begin{tabular}{|c|c|c|c|c|c|c|}
\hline Panel B & $C D S_{t}$ & $C D S_{t}$ & $C D S_{t}$ & $C D S_{t}$ & $C D S_{t}$ & $C D S_{t}$ \\
\hline$D 2 D_{t-1}$ & $\begin{array}{c}-0.990^{* * *} \\
(0.342)\end{array}$ & $\begin{array}{c}-0.911^{* * *} \\
(0.229)\end{array}$ & $\begin{array}{c}-0.023^{* *} \\
(0.274)\end{array}$ & $\begin{array}{c}-0.325 \\
(0.279)\end{array}$ & $\begin{array}{c}-0.758^{* * *} \\
(0.163)\end{array}$ & $\begin{array}{l}0.139 \\
(0.574)\end{array}$ \\
\hline$B A N K \operatorname{SIZE}_{t-1}$ & $\begin{array}{l}0.164 \\
(0.385)\end{array}$ & - & - & - & - & $\begin{array}{c}0.892^{* * *} \\
(0.203)\end{array}$ \\
\hline$H I G H L / E_{t-1}$ & - & $\begin{array}{l}0.080 \\
(0.323)\end{array}$ & - & - & - & $\begin{array}{c}-0.395 \\
(0.399)\end{array}$ \\
\hline$P I I G S_{t-1}$ & - & - & $\begin{array}{c}-2.153^{* * *} \\
(0.785)\end{array}$ & - & - & $\begin{array}{r}-1.958^{* *} \\
(0.799)\end{array}$ \\
\hline BANK DEFAULTED ${ }_{t-1}$ & - & - & - & $\begin{array}{c}-1.452^{* *} \\
(0.727)\end{array}$ & - & $\begin{array}{r}-1.559^{* *} \\
(0.617)\end{array}$ \\
\hline HIGH CDS SPREAD ${ }_{t-1}$ & - & - & - & - & $\begin{array}{c}-0.479^{* * *} \\
(0.185)\end{array}$ & $\begin{array}{r}-0.414^{* *} \\
(0.164)\end{array}$ \\
\hline
\end{tabular}

The results for the bank specific characteristics are reported in Table 4. High leverage, bank size, domicile in a 'problem' country, and a high default risk are the characteristics we tested for a possible amplifying effect of the D2D lead. We also tested whether the fact that a bank has since been defaulted would also strengthen the lead or not. This variable of course overlaps the 
PIIGS dummy in a sense that many of the defaulted banks (except for three) are located in these countries. However, not all banks in PIIGS countries defaulted, which is why we wanted to test whether the lead is related to 'bad' banks or problem countries. The high CDS spread dummy of course proxies a 'bad' bank effect, but it differs from the bank default dummy in a sense that the latter indicates a realized 'bad state' of a bank and the former represents the market's opinion of the banks state. When entered individually into the regression, only being domiciled in PIIGS countries, a high default risk indicated by the CDS spread, and whether the bank was one of those that defaulted during the sample period have a statistically significant strengthening effect on the lead of D2D. The bank's leverage does not seem to have any significant effect on the lead, but the coefficient of the bank size becomes highly significant when all the interactions are introduced into the model at the same time. Because the bank size coefficient is positive, the lead of the D2D is stronger for banks that have a smaller market capitalization than the sample's median market capitalization. All the other interaction coefficients remained almost the same and with the same significance. To conclude, the D2D would have been extremely useful if it had been used in the default risk assessment of a relatively small bank in the PIIGS countries with a high CDS spread during the market turmoil. Overall, we can conclude with rather robust evidence that the hypothesis $2 i v$ ) - vi) hold absolutely, but we have to reject the 2 iii) hypothesis. We continued the analysis after these promising results for the distance-to-default by introducing double interactions for the most promising dummy variables with the lagged D2D variable into the VAR-model. Again the coefficient of the lagged D2D is negative for all model specifications and significant for all models except one. Turmoil on the market combined with a high CDS spread or a domicile in the PIIGS countries seems to have a significantly amplifying effect on the performance of the D2D relative to CDS spreads. The coefficient for the bank size double interaction with a PIIGS domicile is also highly significant and negative.

Table 5

Panel VAR results with conditional dummies

\begin{tabular}{|c|c|c|c|c|c|c|}
\hline Panel C & $C D S_{t}$ & $C D S_{t}$ & $C D S_{t}$ & $C D S_{t}$ & $C D S_{t}$ & $C D S_{t}$ \\
\hline$D 2 D_{t-1}$ & $\begin{array}{c}-0.790^{* * *} \\
(0.168)\end{array}$ & $\begin{array}{c}-0.854^{* * *} \\
(0.176)\end{array}$ & $\begin{array}{c}-0.802^{* * *} \\
(0.169)\end{array}$ & $\begin{array}{c}-0.850^{* * *} \\
(0.173)\end{array}$ & $\begin{array}{r}-0.443^{* *} \\
(0.221)\end{array}$ & $\begin{array}{l}-0.208 \\
(0.231)\end{array}$ \\
\hline TURMOIL * PIIGS $S_{t-1}$ & $\begin{array}{c}-1.722^{* * *} \\
(0.376)\end{array}$ & - & - & - & - & $\begin{array}{r}-0.694^{* *} \\
(0.355)\end{array}$ \\
\hline TURMOIL $*$ SIZE $E_{t-1}$ & - & $\begin{array}{c}-0.172^{* * *} \\
(0.131)\end{array}$ & - & - & - & $\begin{array}{c}0.061 \\
(0.122)\end{array}$ \\
\hline TURMOIL * HIGH CDS SPREAD ${ }_{t-1}$ & - & - & $\begin{array}{c}-1.835^{* * *} \\
(0.337)\end{array}$ & - & - & $\begin{array}{c}-1.836^{* * *} \\
(0.317)\end{array}$ \\
\hline TURMOIL * BANK DEFAULTED ${ }_{t-1}$ & - & - & - & $\begin{array}{c}-0.455 \\
(0.433)\end{array}$ & - & $\begin{array}{c}0.383 \\
(0.432)\end{array}$ \\
\hline$P I I G S * S_{Z I Z E} t_{t-1} \mathrm{t}-1$ & - & - & - & - & $\begin{array}{c}-1.145^{* * *} \\
(0.702)\end{array}$ & $\begin{array}{c}-1.963^{* * *} \\
(0.753)\end{array}$ \\
\hline
\end{tabular}

It seems that there is a lead-lag relationship between the two default risk measures that varies between bank characteristics and general market conditions. The most robust results were that the lead of the distance-to-default over CDS prices is significantly stronger during market turmoil and financial crises, for banks in problem countries, and for banks with high CDS spreads. This promising performance of distance-to-default relative to CDS spreads in default risk assessment 
of European banks can be due to several factors that we can only speculate on here. A relevant issue that needs to be addressed is the share each D2D's component explains of the measures variation. Because stock returns seem to be much more volatile than the liabilities in the banks' balance sheet, it might be that the changes in the values of the D2D - and thus its lead over the CDS spread - is mainly due to the movements in stock prices. To check this possibility, we regressed D2D with the stock returns, volatility of the returns and the banks' liabilities. Then we calculated the partial coefficient of determination for each regressor to see the proportions of explained variance for each variable. The proportions of the explained variance were $15.8 \%$ for stock returns, $40.9 \%$ for the volatility of returns and $43.3 \%$ for the banks liabilities. It seems that the liabilities in bank's balance sheet play a more important role in measuring default risk than is usually thought.

As both measures use market information - one from stock prices and one from CDS prices - the only thing that can affect the difference in performance is the theoretical background of D2D, if we assume that both markets are information efficient. The derivation of D2D assumes, for example, that there are no market frictions and that the firm's asset value follows a geometric Brownian motion, which might not be true all the time. Jessen and Lando (2015) studied the robustness of D2D on deviations from the Merton model assumptions. They found that D2D is a robust measure for ranking different firms according to their default risk despite deviations from most of the assumptions, except for large jumps in the asset value process or if it has stochastic volatility. The other possibility for the lead of the $\mathrm{D} 2 \mathrm{D}$, in addition to the theoretical background of this measure, could be some form of information inefficiency of the CDS markets in some situations. This could indicate that during crises the number of CDS contracts made would decline, because the evaluation of banks' credit risk would be a harder task for the seller and the buyer of the contract. This decline in transaction volume could affect the price discovery process and the markets would not be as information efficient, which would give the distanceto-default a further lead over the CDS spreads. Of course the distance-to-default method also uses market data, but this is from the stock markets, which are probably far more liquid and thus more information efficient ${ }^{10}$. The fact that CDSs are bilateral contracts traded over-the-counter mainly by large institutional investors supports this claim as the CDS markets would be rather 'thin' when compared with stock markets. This kind of inefficiency could be tested by CDS trade volume data, which we do not unfortunately poses. However, the CDS markets have been shown to be efficient in many studies (Zhang and Zhang, 2013; Norden and Weber, 2004) and a lead of one month due to market inefficiency would be quite hard to believe, which is why we have to conclude that the theoretical background is most probably the reason for the better performance of the distance-to-default in many situations. Given these results it is quite interesting to look at the values of the two measures of the individual bank graphs in figure A1. The right axis displays the negative of the D2D and the left axis shows the bank's CDS spread in basis points. If the two measures indicate the same direction of default risk change, then these two lines should go hand in hand. From many of the individual bank graphs it can be seen that around the middle of 2012, the measures seem to move in opposite directions. For almost every individual graph the CDS spread seem to start declining rapidly, which is probably the result of the European central bank president Mario Draghi's "whatever it takes to preserve the euro" speech that calmed the markets. However for the majority of the banks the D2D does not decline as it stays as high as before or begins to rise.

10 Forte and Pena (2009) found that stocks lead the bond and CDS markets more frequently than vice versa. 


\section{CONCLUSIONS}

In this paper we have studied the correlation and short-term dynamics between the CDS spread and the distance-to-default measure for large European banks. In the light of our empirical results from conventional Granger causality analysis in the panel VAR framework, it seems that there is rather robust evidence of a lead-lag relationship between these two highly related default risk measures. In most cases, the lead was one month long, but for some individual banks it was as long as two months. The direction and magnitude of this lead varied with the general market conditions, the banks domicile country, and the bank specific characteristics. The individual bank results were very heterogeneous as there were the same number of banks where the distance-todefault leads CDS spreads and banks where the Granger causality was the other way around. The lead of the distance-to-default seems to become stronger and more significant the further away it is from the beginning of the global financial crises. The market turmoil indicated by a high financial CDS ITRAXX index, a banks domicile in the so called PIIGS countries, and a low credit quality proxied by a high CDS spread has the same strengthening effect on the lead of D2D. The results regarding banks' relative size when compared to the rest of the banks in the sample were mixed as bank size by itself seemed to lower the lead significantly, but when the bank was also in a problem country the effect was the reverse and highly significant.

The promising performance of distance-to-default relative to CDS spread can be motivated by the distance-to-default's theoretical background combined with market information and balance sheet data. The better performance of D2D, especially during market turmoil and financial crises, might indicate that balance sheet information will become increasingly relevant during such market conditions. This was clearly the case during the first stages of the global financial crises of 2008, when the markets were thrown into a panic, as no one knew exactly how many of the toxic subprime mortgages each bank had on their balance sheets. As the more commonly used default risk measure CDS spread relies solely on market information; however, these results imply that a measure with a theoretical background such as the D2D should be used together with the leading market based measure. Using D2D in this way might be very useful in a sense, because it might signal weaknesses in a bank's balance sheet earlier than the CDS spread. The fact that the CDS spread is available for a subset of banks and the D2D can in practice be computed for all banks that are traded on the stock exchange, makes the latter a good alternative as an early warning indicator for the default risk of individual banks. D2D seems to be a good measure for combining information from market prices and balance sheet components. The use of this kind of measure might be a better option for default risk assessment than just using market price data or banks' balance sheet data alone. A further aspects of the subject that could be researched would be the possible generalization of these results. For example, the question could be: Do these relationships between D2D and CDS spreads hold true for banks everywhere or just in Europe and for this time span? It would also be interesting to replicate this analysis e.g. for banks in the U.S. and Asia.

\section{Acknowledgments}

We would like to thank Matti Viren, Heikki Kauppi and Erik Mäkelä for valuable comments during the research and Susmita Baulia for providing proofreading. Also thank you for the anonymous referees for the good comments and the TOP-foundation for financial support. 


\section{References}

Acharya, V.V., Johnson, T.C. (2007) Insider trading in credit derivatives. Journal of Financial Economics 84, pp. 110-141. doi:10.1016/j.jfineco.2006.05.003.

Acharya, V.V., Lochstoer, L.A., Ramadorai, T. (2013) Limits to arbitrage and hedging: Evidence from commodity markets. Journal of Financial Economics 109, pp. 441-465.

Ahmed, J., Anderson, C., Zarutskie, R. (2015) Are the borrowing costs of large financial firms unusual? Finance and Economics Discussion series No 2015-024 http://dx.doi.org/10.17016/FEDS.2015.024.

Arellano, M. (1987) Computing robust standard errors for within-groups estimators. Oxford Bulletin of Economics and Statistics 49, pp. 431-34. doi:10.1111/j.1468-0084.1987.mp49004006.x.

Berg, A., Pattillo, C. (1999) Predicting currency crises: The indicators approach and an alternative. Journal of International Money and Finance 18, pp. 561-586.

Bharath, S., Shumway, T. (2008) Forecasting default with the merton distance to default model. Review of Financial Studies 21, pp. 1339-1369.

Black, F., Scholes, M. S. (1973) The Pricing of Options and Corporate Liabilities. Journal of Political Economy 81, pp. 637-654.

Blanco, R., Brennan, S., Marsh, I.W. (2005) An empirical analysis of the dynamic relation between investment-grade bonds and credit default swaps. The Journal of Finance 60, pp. 2255-2281.

Crosbie, P., Bohn, J. (2003) Modeling default risk. Moody's KMV Company.

Duffie, D. (1999) Credit swap valuation. Financial Analyst Journal 55, pp. 73-87. doi:http://dx.doi.org/10.2469/faj. v55.n1.2243.

Forte, S., Pena, J.I. (2009) Credit spreas: An empirical analysis on the informational content of stocks, bonds and cds. Journal of Banking \& Finance 33, pp. 2013-2025. doi:10.1016/j.jbankfin.2009.04.0152014.

Harada, K., Ito, T., Takahashi, S. (2010) Is the distance to default a good measure in predicting bank failures? case studies. National Bureau of Economic Research Working Paper No 16182. doi: 10.1016/j.japwor.2013.03.007.

Jessen, C., Lando, D. (2015) Robustness of distance-to-default. Journal of Banking \& Finance 50, pp. 493-505. doi: http://dx.doi.org/10.1016/j.jbankfin.2014.05.016.

Juessen, F., Linnemann, L. (2010) Estimating Panel VARs from Macroeconomic Data: Some Monte Carlo Evidence and an Application to OECD Public Spending Shocks. Discussion paper: Sonderforschungsbereich Statistical Modelling of Nonlinear Dynamic Processes, SFB 823 No 24/2010.

Kaminsky, G., Lizondo, S., Reinhart, C.M. (1998) Leading indicators of currencycrises. IMF Staff Paper 45, pp. 1-48.

Merton, R.C. (1974) On the pricing of corporate debt: The risk structure of interest rates. The Journal of Finance 29 , pp. 449-470.

Milne, A. (2014) Distance to default and the financial crises. Journal of financial stability 12, pp. 26-36. doi: http:// dx.doi.org/10.1016/j.jfs.2013.05.005.

Norden, L., Weber, M. (2004) Informational efficiency of credit default swap and stock markets: The impact of credit rating announcements. Journal of Banking \& Finance 28, pp. 2813-2843. doi:10.1016/j.jbankfin.2004.06.011.

Sy, A. N. R., Chan-Lau, J. A. (2006) Distance-To-Default in Banking; A Bridge too Far? IMF Working Papers No 06/215. doi:10.1057/palgrave.jbr.2350056.

Tolo, E., Jokivuolle, E., Viren, M. (2015) Do banks' overnight borrowing rates lead their cds price? evidence from the eurosystem. ECB Working Paper No 1809.

Vlz, M., Wedow, M. (2011) Market discipline and too-big-to-fail in the cds market: Does banks' size reduce market discpline? Journal of Empirical Finance 18, pp. 195-210. doi:10.1016/j.jempfin.2011.01.001.

Zhang, G., Zhang, S. (2013) Information efficiency of the u.s. credit default swap market: Evidence from earnings surprises. Journal of financial stability 9, pp. 720-730. doi:10.1016/j.jfs.2011.10.005. 


\section{APPENDIX}

Table A1

List of Banks

\begin{tabular}{|c|c|c|c|}
\hline Bank & Country & $\mathrm{N}$ & Default ${ }^{*}$ \\
\hline Danske Bank & Denmark & 96 & \\
\hline BNP paribas & France & 96 & \\
\hline Societe generale & France & 96 & \\
\hline Credit agricole & France & 96 & \\
\hline Commerzbank & Germany & 96 & \\
\hline Deutsche bank & Germany & 84 & \\
\hline $\mathrm{IKB}$ & Germany & 36 & \\
\hline UBI Banca & Italy & 96 & \\
\hline Allied Irish Banks & Ireland & 96 & $2010-9$ \\
\hline Bank of Ireland & Ireland & 57 & $2010-9$ \\
\hline Banca Popolare di Milano & Italy & 57 & \\
\hline Banco popolare societa cooperativa & Italy & 73 & \\
\hline ING Groep & Netherlands & 96 & \\
\hline Banco Comercial Português & Portugal & 96 & \\
\hline Banco Bilbao Vizcaya argentaria & Spain & 57 & \\
\hline Bankinter & Spain & 96 & \\
\hline Banco popular espanol & Spain & 66 & \\
\hline Banco de Sabadell & Spain & 68 & \\
\hline Barclays & UK & 96 & \\
\hline Royal Bank of Scotland Group & UK & 72 & $2008-10$ \\
\hline Svenska Handelsbanken & Sweden & 96 & \\
\hline Swedbank & Sweden & 96 & \\
\hline HSBC Holdings & UK & 70 & \\
\hline DNB Bank & Norway & 70 & \\
\hline Alpha Bank & Greece & 96 & $2012-8$ \\
\hline National bank of Greece & Greece & 61 & $2012-6$ \\
\hline Lloyds Banking Group & UK & 96 & $2012-6$ \\
\hline Mediobanca & Italy & 96 & $2008-11$ \\
\hline Dexia & Belgium & 96 & 2008-9; 2011-10 \\
\hline Banco BPI & Portugal & 57 & \\
\hline Erste Group & Austria & 96 & \\
\hline Intesa Sanpaolo & Italy & 89 & \\
\hline UniCredit & Italy & 42 & \\
\hline Banco Santander & Spain & 72 & \\
\hline Nordea & Sweden & 96 & \\
\hline Eurobank Ergasis & Greece & 72 & $2011-7 ; 2012-6$ \\
\hline Banca Monte dei Pachi di Siena & Italy & 96 & \\
\hline
\end{tabular}

Note: * We count mergers, bailouts, nationalizations and separations from the main bank as defaults. 
Table A2

Panel unitroot test summary for CDS spread and D2D

Sample: 1/02/2006 12/02/2013

Exogenous variables: Individual effects

Automatic lag length selection based on SIC: 0 to 2

Newey-West automatic bandwidth selection and Bartlett kernel

\section{D2D}

Method Statistic

Prob.**

Cross-sections

Obs

Null: Unit root (assumes common unit root process)

Levin, Lin and Chu t*

$-5.09749 \quad 0.0000$

Null: Unit root (assumes individual unit root process)

Im, Pesaran and Shin W-stat

$-3.04526$

0.0012

37

2963

$\mathrm{ADF}$ - Fisher Chi-square

115.607

0.0014

2963

$\mathrm{PP}$ - Fisher Chi-square

145.133

0.0000

37

2986

CDS spread

Method

Statistic

Prob. ${ }^{* *}$

Cross-sections

Obs

Null: Unit root (assumes common unit root process)

Levin, Lin and Chu t*

$-1.25774$

0.1042

37

2981

Null: Unit root (assumes individual unit root process)

Im, Pesaran and Shin W-stat

$-1.06573$

0.1433

$\mathrm{ADF}$ - Fisher Chi-square

73.9877

0.4785

2981

$\mathrm{PP}$ - Fisher Chi-square

72.1279

0.5399

37

2986

** Probabilities for Fisher tests are computed using an asymptotic Chi square distribution. All other tests assume asymptotic normality.

Table A3

Granger causality analysis of CDS and D2D in differences with fixed effects VAR-model

\begin{tabular}{lcc}
\hline & \multicolumn{2}{c}{ Dependent variable: } \\
\hline & $\Delta D 2 D_{t}$ & $\Delta C D S_{t}$ \\
\hline$\Delta C D S_{t}$ & 0.001 & $0.070^{*}$ \\
& $(0.0007)$ & $(0.042)$ \\
$\Delta D 2 D_{t}$ & $-0.177^{* *}$ & $-0.733^{* * *}$ \\
& $(0.082)$ & $(0.231)$ \\
$\mathrm{H} 0: \Delta C D S$ does not Granger cause $\triangle D 2 D$ & 0.485 & 0.002 \\
$\mathrm{H} 0: \Delta D 2 D$ does not Granger cause $\triangle C D S$ & & 3,021 \\
\hline Observations & 3,021 & 0.034 \\
$R^{2}$ & 0.010 & \\
\hline \hline
\end{tabular}

Note: ${ }^{*} \mathrm{p}<0.1 ;{ }^{* *} \mathrm{p}<0.05 ;{ }^{* * *} \mathrm{p}<0.01$ 
Table A4

Granger causality results for individual banks for levels

\begin{tabular}{|c|c|c|c|c|}
\hline & & $\begin{array}{l}\text { H0: CDS does } \\
\text { not cause D2D }\end{array}$ & $\begin{array}{l}\text { H0: D2D does } \\
\text { not cause CDS }\end{array}$ & \\
\hline Bank & lag & p-value & p-value & Causality \\
\hline Danske Bank & 1 & 0.195 & 0.853 & No granger causality \\
\hline BNP paribas & 2 & 0.305 & 0.017 & D2D Granger causes CDS spreads \\
\hline Societe generale & 2 & 0.038 & 0.095 & CDS Spread Granger Causes D2D \\
\hline Credit agricole & 2 & 0.119 & 0.027 & D2D Granger causes CDS spreads \\
\hline Commerzbank & 1 & 0.281 & 0.010 & D2D Granger causes CDS spreads \\
\hline Deutsche bank & 1 & 0.040 & 0.285 & CDS Spread Granger Causes D2D \\
\hline IKB & 1 & 0.048 & 0.080 & CDS Spread Granger Causes D2D \\
\hline UBI Banca & 1 & 0.009 & 0.067 & CDS Spread Granger Causes D2D \\
\hline Allied Irish Banks & 1 & 0.155 & 0.102 & No granger causality \\
\hline Bank of Ireland & 1 & 0.017 & 0.012 & bidirectional Granger causality \\
\hline Banca Popolare di Milano & 1 & 0.167 & 0.006 & D2D Granger causes CDS spreads \\
\hline Banco popolare societa cooperativa & 1 & 0.068 & 0.019 & D2D Granger causes CDS spreads \\
\hline ING Groep & 1 & 0.080 & 0.757 & No granger causality \\
\hline Banco Comercial Português & 1 & 0.021 & 0.051 & CDS Spread Granger Causes D2D \\
\hline Banco Bilbao Vizcaya argentaria & 1 & 0.055 & 0.802 & No granger causality \\
\hline Bankinter & 2 & 0.091 & 0.021 & D2D Granger causes CDS spreads \\
\hline Banco popular espanol & 1 & 0.771 & 0.100 & No granger causality \\
\hline Banco de Sabadell & 1 & 0.441 & 0.006 & D2D Granger causes CDS spreads \\
\hline Barclays & 2 & 0.001 & 0.464 & CDS Spread Granger Causes D2D \\
\hline Royal Bank of Scotland Group & 1 & 0.011 & 0.094 & CDS Spread Granger Causes D2D \\
\hline Svenska Handelsbanken & 1 & 0.000 & 0.125 & CDS Spread Granger Causes D2D \\
\hline Swedbank & 4 & 0.533 & 0.148 & No granger causality \\
\hline HSBC Holdings & 1 & 0.061 & 0.382 & No granger causality \\
\hline DNB Bank & 1 & 0.000 & 0.094 & CDS Spread Granger Causes D2D \\
\hline Alpha Bank & 1 & 0.904 & 0.082 & No granger causality \\
\hline National bank of Greece & 1 & 0.054 & 0.099 & No granger causality \\
\hline Lloyds Banking Group & 1 & 0.101 & 0.047 & D2D Granger causes CDS spreads \\
\hline Mediobanca & 1 & 0.120 & 0.000 & D2D Granger causes CDS spreads \\
\hline Dexia & 1 & 0.218 & 0.617 & No granger causality \\
\hline Banco BPI & 1 & 0.709 & 0.179 & No granger causality \\
\hline Erste Group & 1 & 0.001 & 0.167 & CDS Spread Granger Causes D2D \\
\hline Intesa Sanpaolo & 1 & 0.406 & 0.562 & No granger causality \\
\hline UniCredit SpA & 1 & 0.095 & 0.352 & No granger causality \\
\hline Banco Santander & 1 & 0.324 & 0.071 & No granger causality \\
\hline Nordea & 1 & 0.215 & 0.363 & No granger causality \\
\hline Eurobank Ergasis & 2 & 0.596 & 0.312 & No granger causality \\
\hline Banca Monte dei Paschi di Siena S.p.A. & 1 & 0.822 & 0.016 & D2D Granger causes CDS spreads \\
\hline
\end{tabular}


Figure A1

CDS spread and the negative of distance-to-default for different banks

\section{Commerzbank}

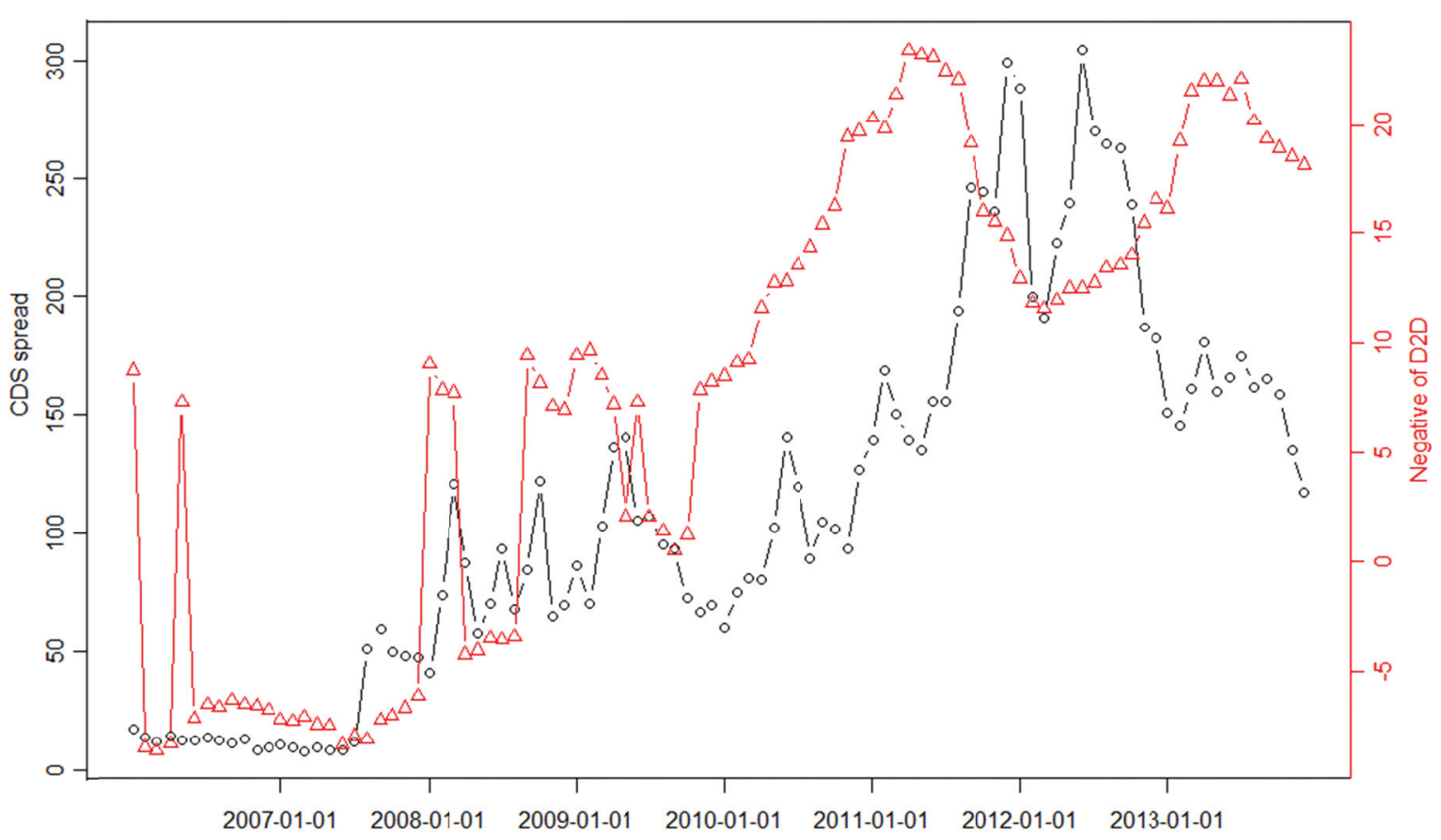

\section{Dexia}

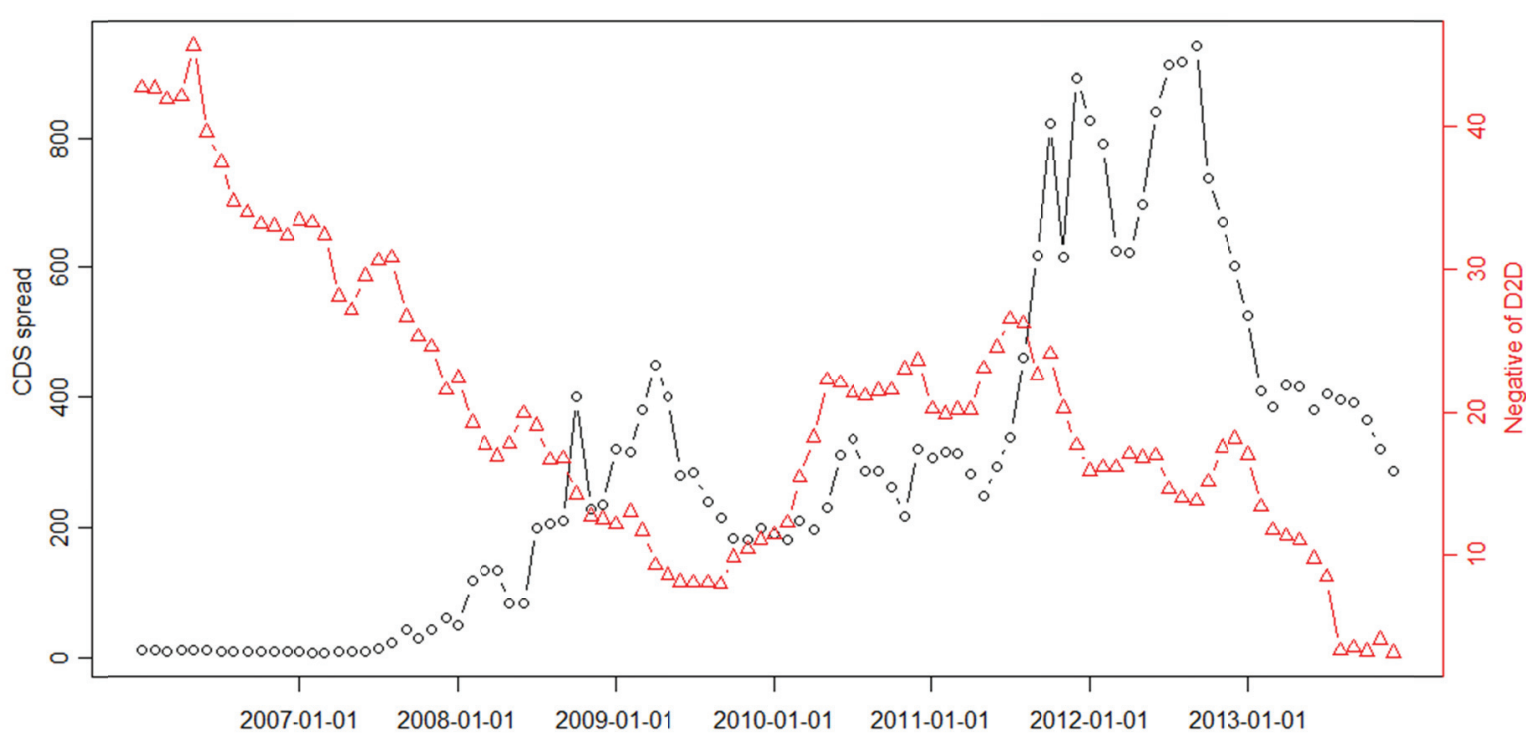




\section{DNB Bank}

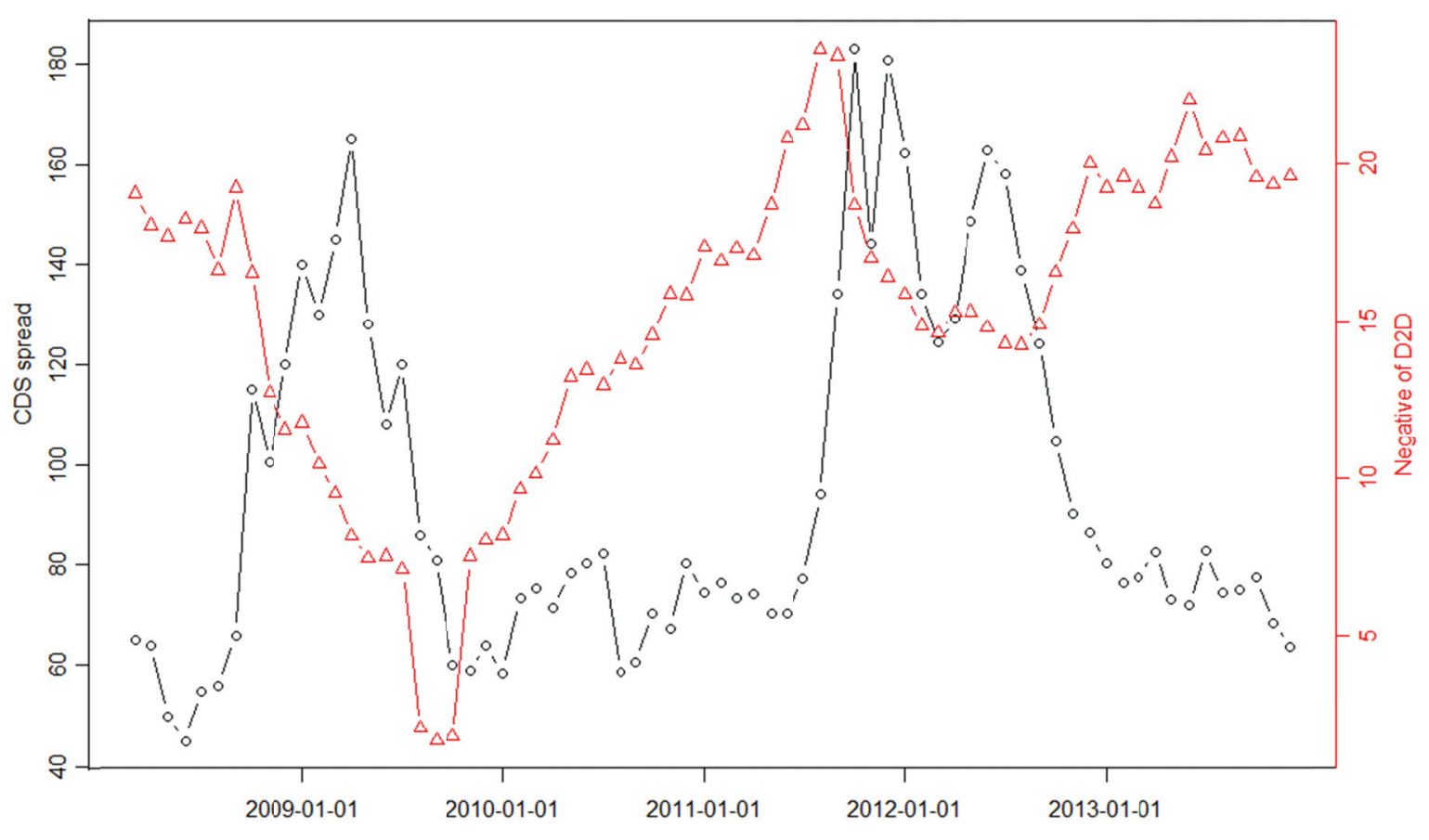

Lloyds Banking Group

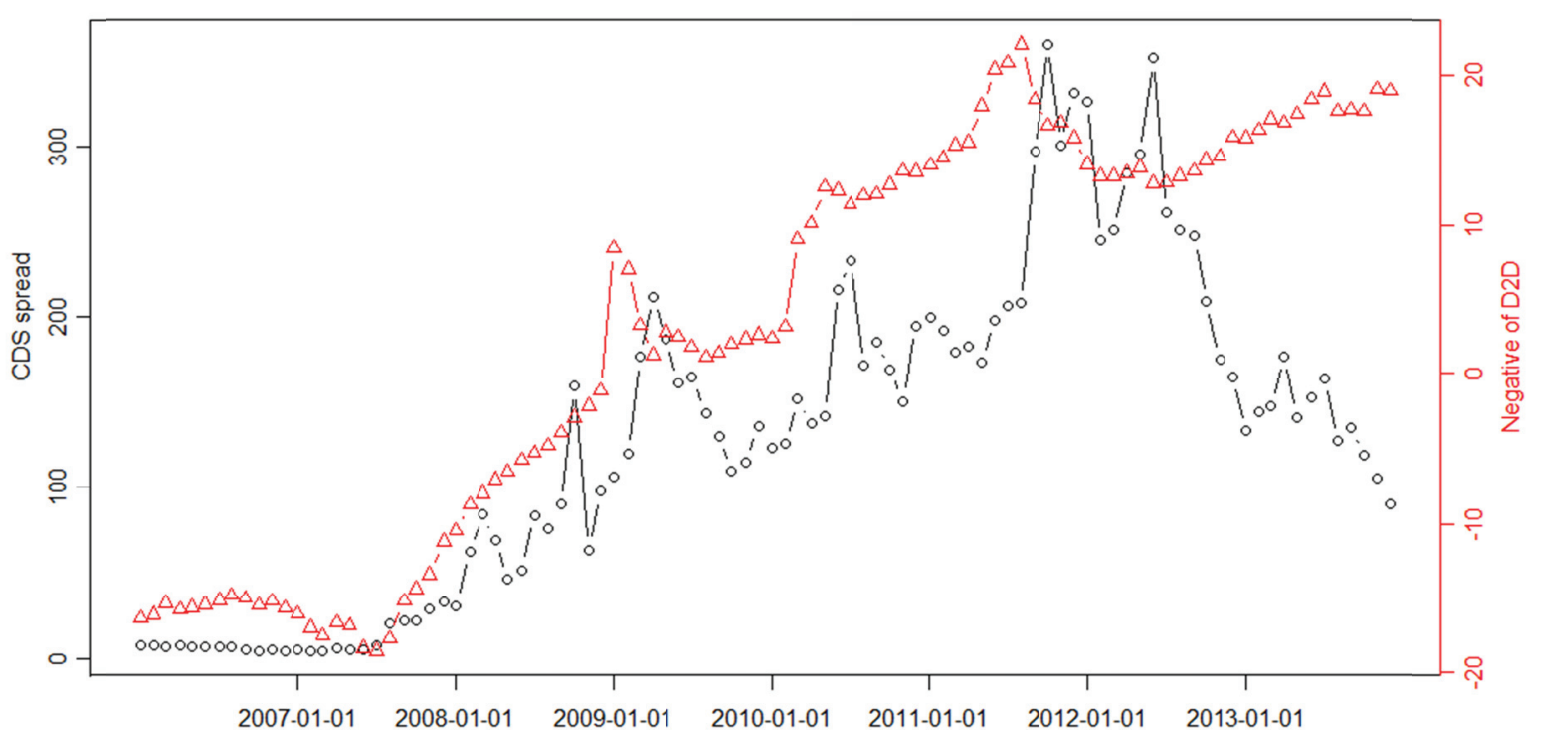


Mediobanka

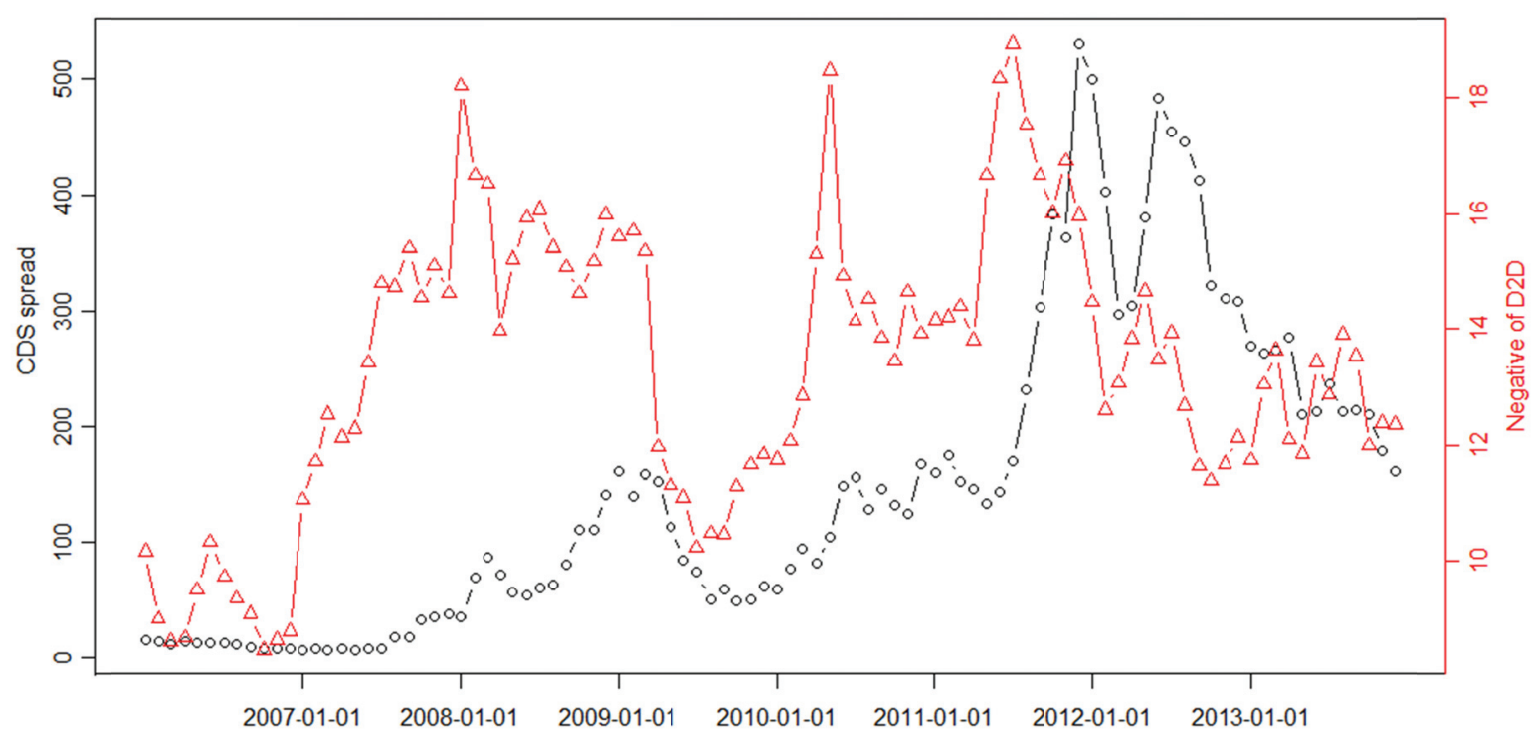

Banka Monte dei Paschi di Siena S.p.A.

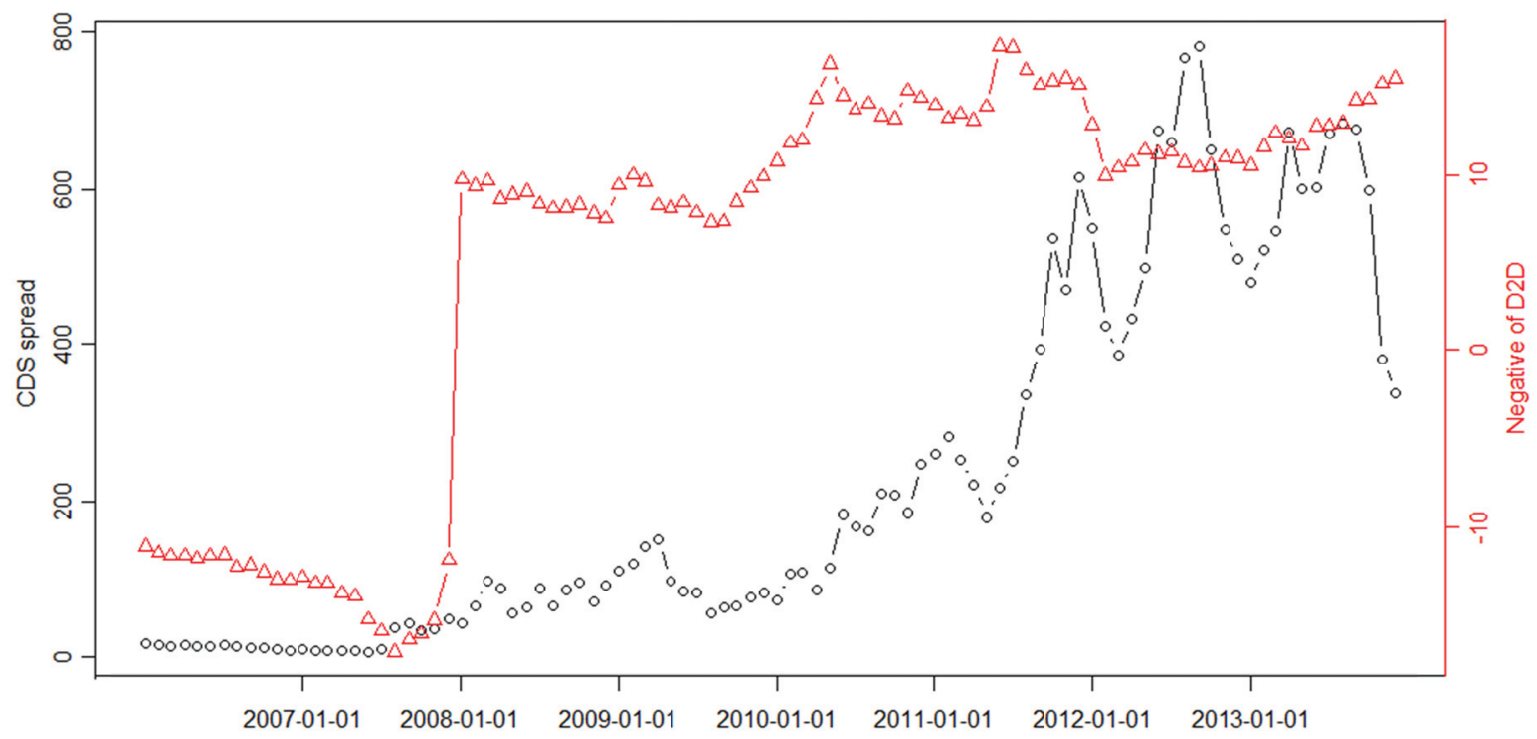




\section{Royal Bank of Scotland Group}

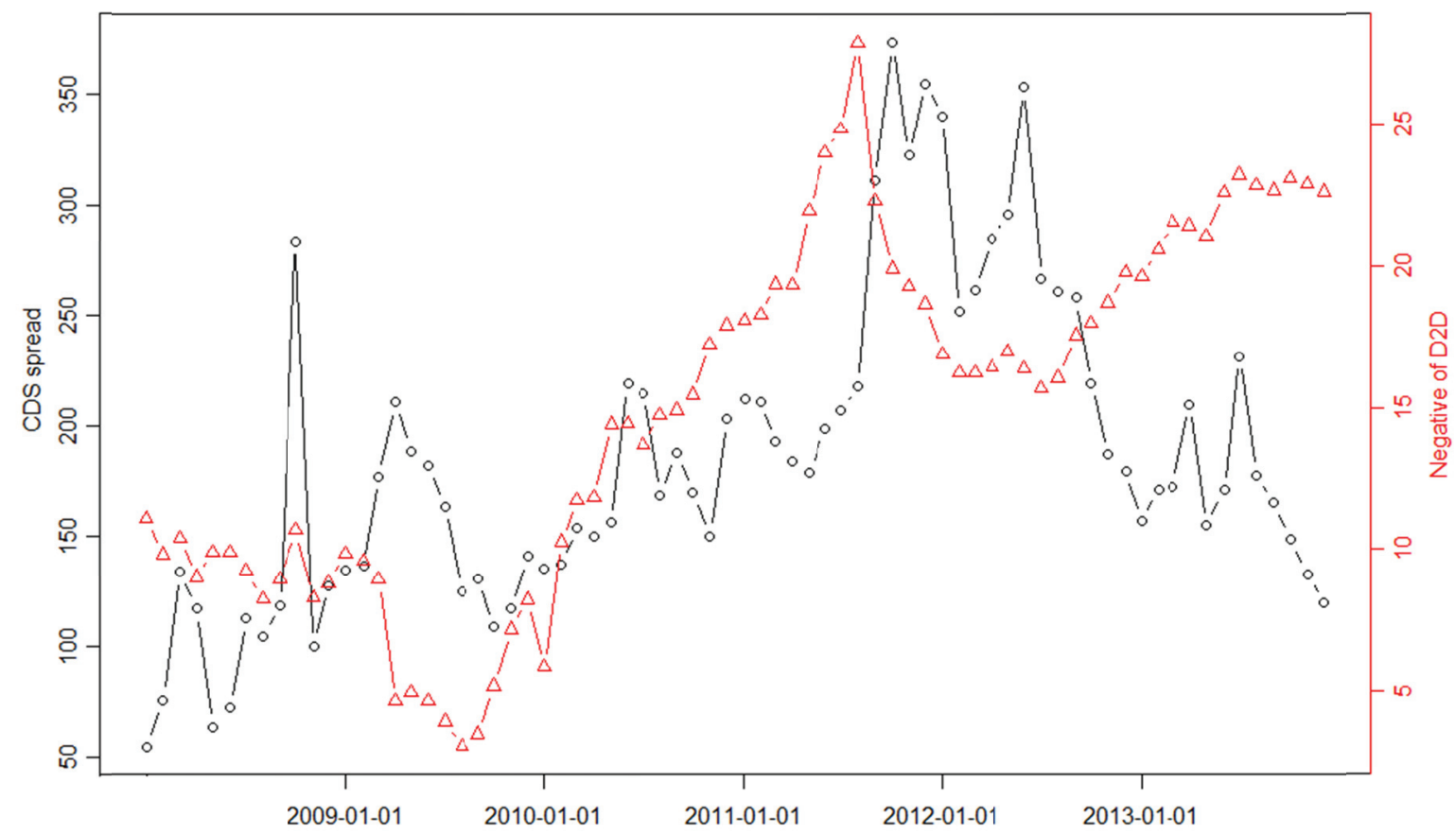

Banko Santander

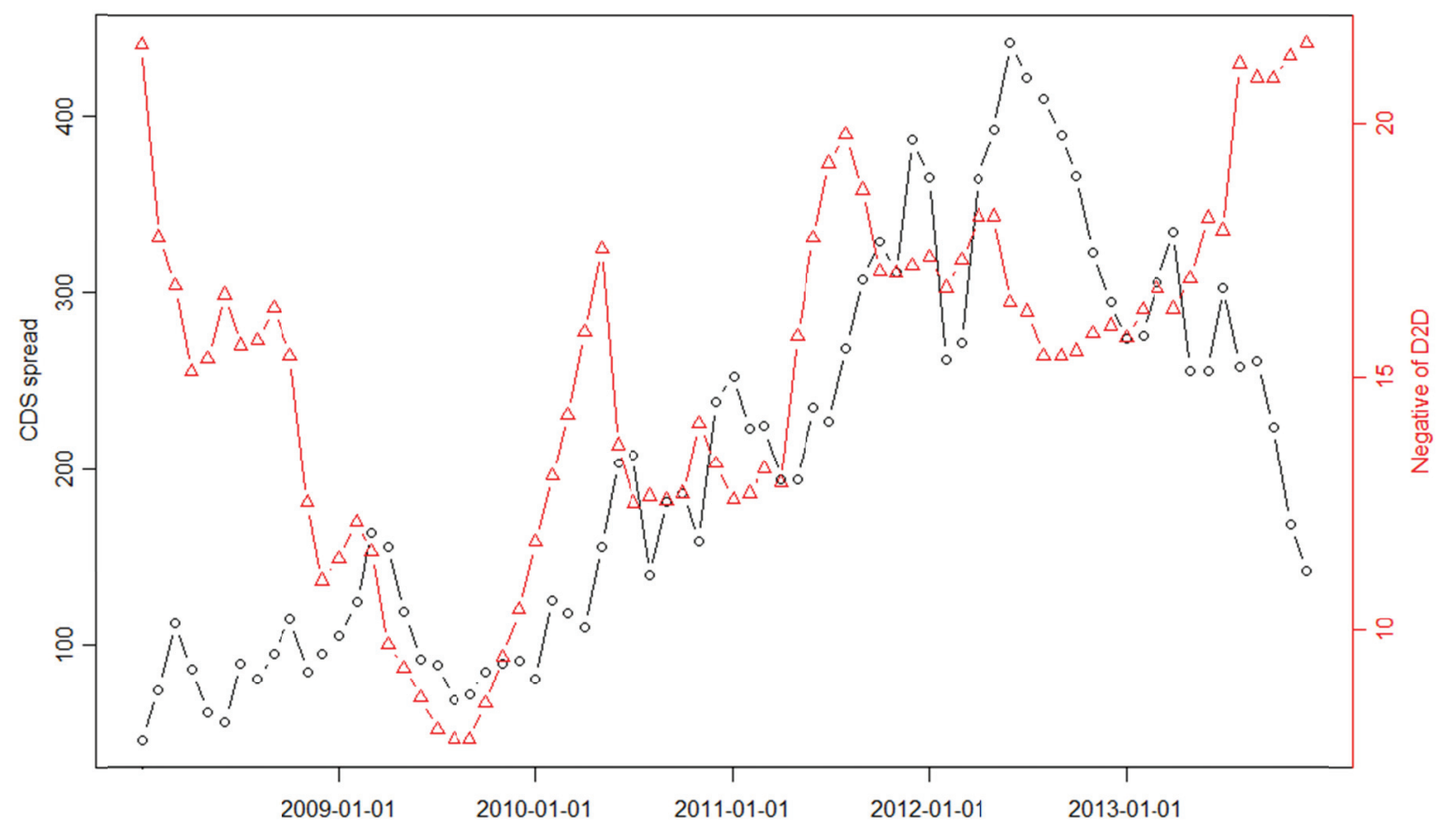

